\title{
Profil Kemampuan Kognitif dan Keterampilan Berpikir Kritis Siswa SMA pada Materi Usaha dan Energi
}

\author{
Syifa Nurazizaha) ${ }^{\text {a) }}$ Parlindungan Sinaga ${ }^{\text {b) }}$, Agus Jauharic ${ }^{\text {( }}$ \\ Departemen Pendidikan Fisika FPMIPA UPI, Jl. Dr. Setiabudhi No.229, Bandung 40154

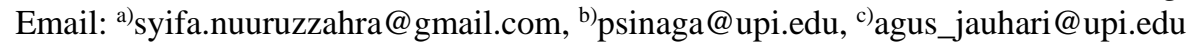

\begin{abstract}
This study aims to determine the profile of cognitive ability. The research method used descriptive quantitative. The research subjects are 50 eleventh graders from two high schools in Bandung. The research instrument used multiple choice questions with five options to measure cognitive ability and essay questions for 4 of 5 critical thinking skill's indicators by Ennis's. This study uses descriptive analysis techniques based on the percentage of cognitive abilities and critical thinking skill. The results showed on cognitive ability, $62.00 \%$ of students are able in $\mathrm{C} 1$ cognitive domain; $31.30 \%$ are able in cognitive domain $\mathrm{C} 2 ; 21.30 \%$ are able in C3 cognitive domain; $25.00 \%$ are able in $\mathrm{C} 4$ cognitive domain; And on critical thinking skill, that is; $28.00 \%$ of students are able to identify stated reasons; $10.67 \%$ are able to agreement among sources; $11.33 \%$ are able to inter explanatory conclussions and hypotheses; And $6.00 \%$ are able to select criteria to judge possible solutions. The implication is, student's cognitive ability and critical thinking skill are still low, so there must be an effort to improve them through learning innovations.
\end{abstract}

Keywords: cognitive ability, critical thinking skill, work and energy

\begin{abstract}
Abstrak
Penelitian ini bertujuan untuk mengetahui profil kemampuan kognitif dan keterampilan berpikir kritis siswa SMA pada materi usaha dan energi. Metode penelitian yang digunakan adalah deskriptif kuantitatif. Subjek penelitian sebanyak 50 siswa kelas XI dari dua Sekolah Menengah Atas di Kota Bandung. Instrumen penelitian menggunakan soal pilihan ganda dengan lima option untuk mengukur kemampuan kognitif dan soal uraian untuk mengukur 4 dari 5 indikator keterampilan berpikir kritis yang dikemukakan oleh Ennis. Analisis data menggunakan teknik analisis deskriptif berdasarkan persentase kemampuan kognitif dan keterampilan berpikir kritis siswa. Hasil penelitian menunjukkan bahwa pada kemampuan kogitif, 62,00\% siswa mampu dalam ranah kognitif $\mathrm{C} 1 ; 31,30 \%$ siswa mampu dalam ranah kognitif $\mathrm{C} 2 ; 21,30 \%$ siswa mampu dalam ranah kognitif $\mathrm{C} 3 ; 25,00 \%$ siswa mampu dalam ranah kognitif $\mathrm{C} 4$; dan pada keterampilan berpikir kritis siswa yaitu, 28,00\% siswa mampu dalam indikator mengidentifikasi alasan yang dinyatakan; 10,67\% siswa mampu dalam indikator persetujuan di antara sumber; $11,33 \%$ siswa mampu dalam indikator menyimpulkan penjelasan, kesimpulan, dan hipotesis; serta 6,00\% siswa mampu dalam indikator memilih kriteria untuk mempertimbangkan solusi yang mungkin. Implikasinya, kemampuan kognitif dan keterampilan berpikir kritis siswa masih tergolong rendah, sehingga harus ada upaya untuk meningkatkannya melalui inovasi-inovasi pembelajaran.
\end{abstract}

Kata-kata Kunci: kemampuan kognitif, keterampilan berpikir kritis, usaha dan energi 


\section{PENDAHULUAN}

Kompetensi yang harus dicapai oleh siswa SMA/ MA/ SMALB/ PAKET C berdasarkan Permendikbud No. 21 Tahun 2016 tentang Standar Isi Pendidikan Dasar Menengah pada muatan fisika, butir (1) yaitu "Mengembangkan sikap rasa ingin tahu, jujur, tanggung jawab, logis, kritis, analitis, dan kreatif melalui pembelajaran fisika" dan butir (3) yaitu "Menganalisis konsep, prinsip, dan hukum mekanika, fluida, termodinamika, gelombang, dan optik serta menerapkan metakognisi dalam menjelaskan fenomena alam dan penyelesaian masalah kehidupan".

Pada butir ke-(1) di atas, disebutkan bahwa kompetensi yang harus dicapai siswa salah satunya yaitu mengembangkan sikap ktitis. Sikap kritis dapat dicapai jika siswa memiliki keterampilan berpikir kritis. Selain itu, pada butir ke-(3) di atas menyebutkan bahwa kompetensi yang harus dimiiki siswa adalah menganalisis konsep, prinsip, dan hukum Fisika. Kompetensi tersebut termasuk ke dalam kemampuan kognitif, sehingga kemampuan kognitif dan keterampilan berpikir kritis merupakan hal yang sangat penting dalam proses pembelajaran. Oleh sebab itu, guru sebagai pendidik diharapkan dapat memfasilitasi untuk menumbuhkembangkan kemampuan kognitif dan keterampilan berpikir kritis siswa.

Berpikir kritis adalah berpikir reflektif dan beralasan yang berfokus pada pengambilan keputusan tentang apa yang harus dipercaya atau dilakukan (Ennis 1985). Lai (2011) mengemukakan bahwa dalam keterampilan berpikir kritis, siswa dituntut untuk dapat menganalisis argumen, membuat kesimpulan menggunakan penalaran induktif atau deduktif, menilai atau mengevaluasi, dan membuat keputusan atau memecahkan masalah. Siswa dalam memecahkan suatu masalah, harus mengetahui dan memahami masalahnya terlebih dahulu, sehingga dalam hal ini pengetahuan teoritis dapat mempengaruhi penilaian dan pengambilan keputusan mereka. Oleh karena itu, kemampuan kognitif sangat berperan dalam berpikir kritis. Yu, KC, Lin, KY dan Fan, SC (2014) menyatakan bahwa kemampuan kognitif berkaitan erat dengan keterampilan berpikir kritis. Hal ini berarti untuk menumbuhkembangkan keterampilan berpikir kritis, harus bersamaan dengan melatihkan kemampuan kognitif pada siswa.

Kemampuan kognitif merupakan kemampuan yang berkaitan dengan kecerdasan seseorang. Utari (2012) menyebutkan bahwa ranah kognitif berisi perilaku yang menekankan aspek intelektual seperti pengetahuan dan keterampilan berpikir.

Dalam taksonomi Bloom revisi, Krathwohl (2002) mendefinisikan kategori ranah kognitif sebagai berikut:

a. C1. Mengingat (remember) - mengambil pengetahuan yang relevan dari memori jangka panjang;

b. C2. Memahami (understand) - menentukan maksud dari materi pembelajaran, termasuk komunikasi lisan, tertulis, dan grafis;

c. C3. Mengaplikasikan (apply) - melaksanakan dan menggunakan prosedur dalam situasi tertentu;

d. C4. Menganalisis (analyze) - memecah materi kedalam bagian-bagian penyusunnya dan mendeteksi bagaimana bagian-bagian tersebut berhubungan satu sama lain;

e. C5. Mengevaluasi (evaluate) - mengambil keputusan berdasarkan kriteria dan standar;

f. C6. Membuat (create) - meletakkan berbagai unsur untuk membentuk suatu yang baru, berhubungan, atau membuat suatu hasil yang asli.

Keterampilan berpikir kritis akan dapat dicapai seseorang yang mempunyai kemampuan kognitif. Hal ini dikarenakan dalam memecahkan suatu masalah, seseorang tersebut harus mengetahui dan memahami masalahnya terlebih dahulu. Oleh karena itu, kemampuan kognitif sangat berperan dalam berpikir kritis. Keterampilan berpikir kritis tersebut bukan merupakan bawaan sejak lahir melainkan muncul ketika dilatihkan atau diterapkan melalui proses pembelajaran oleh pendidik sebagai fasilitator dalam pembelajaran tersebut. Sehingga inovasi-inovasi dalam suatu proses pembelajaran akan dapat menumbuhkan dan meningkatkan kemampuan kognitif serta keterampilan berpikir kritis siswa.

Ennis (1985) mengemukaan bahwa terdapat 12 sub keterampilan berpikir kritis yang dikelompokannya dalam lima kategori sebagai berikut: 
a. Memberikan penjelasan sederhana, yang terdiri atas memfokuskan pertanyaan, menganalisis pertanyaan serta bertanya dan menjawab pertanyaan tentang suatu penjelasan;

b. Membangun keterampilan dasar, yang terdiri atas mempertimbangkan apakah sumber dapat dipercaya atau tidak serta mengobservasi dan mempertimbangkan suatu laporan hasil observasi;

c. Menyimpulkan, yang terdiri atas mendeduksi dan mempertimbangkan hasil deduksi, menginduksi dan mempertimbangkan hasil induksi, serta membuat dan menentukan hasil pertimbangan;

d. Memberikan penjelasan lanjut, yang terdiri atas mengidentifikasi istilah dan mempertimbangkan suatu definisi dalam tiga dimensi, serta mengidentifikasi asumsi;

e. Mengatur strategi dan taktik, yang terdiri atas menentukan tindakan dan berinteraksi dengan orang lain.

Berdasarkan pemaparan di atas, fokus penelitian ini pada kemampuan kognitif dan keterampilan berpikir kritis siswa SMA. Tujuan dari penelitian ini yaitu untuk mengetahui profil kemampuan kognitif dan keterampilan berpikir kritis siswa pada materi usaha dan energi. Pertanyaan yang akan dijawab yaitu bagaimana profil kemampuan kognitif dan keterampilan berpikir kritis siswa SMA pada materi usaha dan energi.

\section{METODE PENELITIAN}

Metode yang digunakan untuk mengetahui profil kemampuan kognitif dan keterampilan berpikir kritis siswa dalam penelitian ini yaitu deskriptif kuantitatif. Subjek penelitian sebanyak 50 siswa kelas XI Tahun Akademik 2016/2017 dari dua Sekolah Menengah Atas di Kota Bandung.

Data diperoleh melalui instrumen penelitian yang menggunakan soal pilihan ganda dengan lima option untuk mengukur kemampuan kognitif pada ranah kognitif $\mathrm{C} 1-\mathrm{C} 4$, jumlah soal sebanyak 12 butir pilihan ganda yang terdistribusi pada ranah kognitif C1-C4 (3 soal C1, 3 soal C2, 3 soal C3, dan 3 soal C4). Selain itu, digunakan juga soal uraian untuk mengukur keterampilan berpikir kritis yang dikontruksi dengan menggunakan 4 dari 5 indikator berdasarkan indikator keterampilan berpikir kritis yang dikemukakan oleh Ennis. Jumlah soal yang digunakan sebanyak 12 butir yang masing-masing 3 butir soal untuk setiap indikator keterampilan berpikir kritis. Indikator yang dipakai tersebut merupakan indikator pada setiap sub keterampilan berpikir kritis, diantaranya: mengidentifikasi alasan yang dinyatakan pada sub keterampilan menganalisis argumen; persetujuan di antara sumber pada sub keterampilan mempertimbangkan apakah sumber dapat dipercaya atau tidak; menyimpulkan penjelasan, kesimpulan, dan hipotesis pada sub keterampilan menginduksi dan mempertimbangkan hasil induksi; serta memilih kriteria untuk mempertimbangkan solusi yang mungkin pada sub keterampilan menentukan suatu tindakan. Jawaban soal uraian dinilai menggunakan rubrik dengan mengacu pada rubrik penskoran menurut Stiggins (1994) yang diuraikan pada TABEL 1.

TABEL 1. Pedoman Pemberian Skor Soal Uraian Berpikir Kritis

\begin{tabular}{cl}
\hline Skor & \multicolumn{1}{c}{ Indikator Penilaian } \\
\hline 5 & $\begin{array}{l}\text { Jawaban yang diberikan jelas, fokus, dan akurat. Hubungan antara jawaban soal tergambar } \\
\text { jelas }\end{array}$ \\
& $\begin{array}{l}\text { Jawaban yang diberikan jelas dan cukup fokus, namun kurang lengkap. Keterkaitan antara } \\
\text { jawaban dengan soal kurang akurat }\end{array}$ \\
& $\begin{array}{l}\text { Jawaban yang diberikan kurang sesuai dengan apa yang dimaksudkan dalam soal, berisi } \\
\text { informasi yang tidak akurat, atau menunjukan kurangnya penguasaan terhadap materi. } \\
\text { Poin-poin yang diberikan tidak jelas, tidak memberikan contoh yang mendukung }\end{array}$ \\
& Tidak ada jawaban \\
\hline
\end{tabular}

Data yang telah terkumpul kemudian diolah dan dianalisis menggunakan teknik analisis deskriptif berdasarkan persentase siswa yang menjawab benar dan salah dari tes kemampuan kognitif dan keterampilan berpikir kritis yang diberikan. Adapun tafsiran persentasenya berdasarkan pada tafsiran yang dikemukakan oleh Arikunto (2012) disajikan dalam TABEL 2. 
TABEL 2. Tafsiran kemampuan kognitif dan keterampilan berpikir kritis.

\begin{tabular}{ccc}
\hline No & Persentase (\%) & Tafsiran \\
\hline 1 & 0 & Tidak ada \\
2 & $1-25$ & Sebagian kecil \\
3 & $26-49$ & Hampir setengahnya \\
4 & 50 & Setengahnya \\
5 & $51-75$ & Sebagian besar \\
6 & $76-99$ & Hampir seluruhnya \\
7 & 100 & Seluruhnya \\
\hline
\end{tabular}

\section{HASIL DAN PEMBAHASAN}

Data yang diperoleh untuk setiap ranah kognitif pada kemampuan kognitif dan setiap indikator pada keterampilan berpikir kritis diolah dengan perhitungan berikut:

$$
\frac{\text { Rata - rata siswa yang menjawab benar }}{\text { Jumlah keseluruhan siswa }} \times 100 \%
$$

Hasil pengolahan dan analisis presentase kemampuan kognitif dan keterampilan berpikir kritis siswa disajikan dalam GAMBAR 1 dan GAMBAR 2 sebagai berikut:

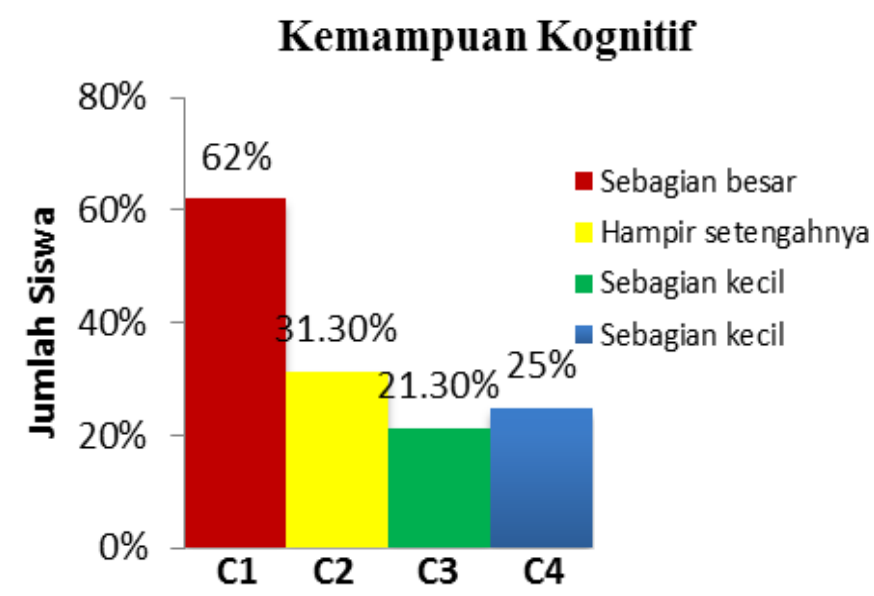

GAMBAR 1. Profil kemampuan kognitif siswa

\section{Keterampilan Berpikir Kritis}

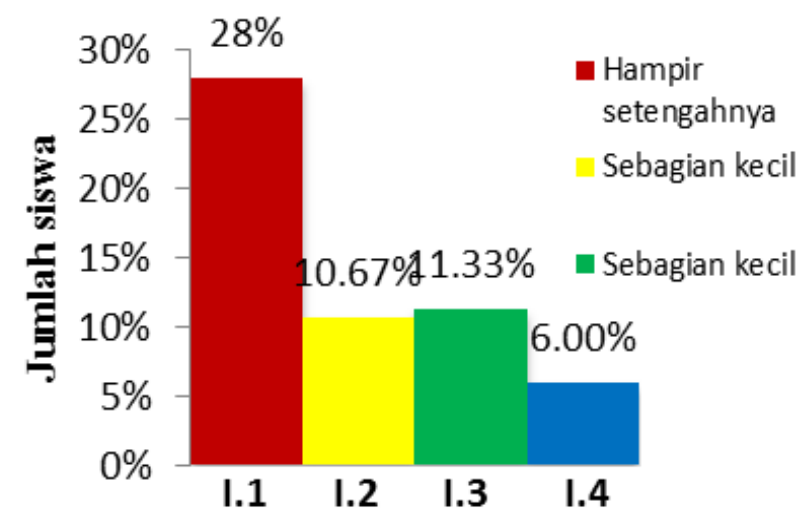

GAMBAR 2. Profil keterampilan berpikir kritis siswa 
Pada kemampuan kognitif berdasarkan GAMBAR 1, diketahui bahwa dari keseluruhan jumlah siswa, 62,00\% siswa bisa mengerjakan soal $\mathrm{C} 1,31,30 \%$ siswa bisa mengerjakan soal C2, 21,30\% bisa mengerjakan soal C3, dan $25,00 \%$ bisa mengerjakan soal C4. Sehingga, sebagian besar siswa mampu dalam ranah kognitif $\mathrm{CI}$, hampir setengahnya dari siswa mampu dalam ranah kognitif $\mathrm{C} 2$, serta dalam ranah kognitif $\mathrm{C} 3$ dan $\mathrm{C} 4$ hanya sebagian kecil siswa mampu dalam menguasainya. Kemudian pada keterampilan berpikir kritis berdasarkan GAMBAR 2, diketahui bahwa dari keseluruhan jumlah siswa, 28\% siswa bisa mengerjakan soal pada indikator mengidentifikasi alasan yang dinyatakan, $10,67 \%$ siswa bisa mengerjakan soal indikator persetujuan di antara sumber, $11,33 \%$ siswa bisa mengerjakan soal pada indikator menyimpulkan penjelasan, kesimpulan, dan hipotesis, dan 6,00\% siswa bisa mengerjakan soal pada indikator memilih kriteria untuk mempertimbangkan solusi yang mungkin. Sehingga, hampir setengahnya siswa mampu menguasai dalam indikator mengidentifikasi alasan yang dinyatakan. Sedangkan dalam indikator persetujuan di antara sumber; menyimpulkan penjelasan, kesimpulan, dan hipotesis; serta indikator memilih kriteria untuk mempertimbangkan solusi yang mungkin, hanya sebagian kecil siswa yang mampu menguasainya.

Hasil data tersebut menunjukkan bahwa kemampuan kognitif dan keterampilan berpikir kritis siswa masih tergolong rendah. Hal ini berarti masih banyak siswa yang sulit menguasai kemampuan kognitif dan keterampilan berpikir kritis. Rendahnya kemampuan kognitif dan keterampilan berpikir kritis siswa dapat disebabkan oleh beberapa faktor, beberapa diantaranya yaitu penerapan strategi pembelajaran yang kurang sesuai serta tidak adanya pembiaasaan yang dapat melatih siswa untuk mengembangkan kemampuan kognitif dan keterampilan berpikir kritis.

Upaya untuk meningkatkan kemampuan kognitif dan keterampilan berpikir kritis siswa dapat dilakukan melalui inovasi-inovasi pembelajaran. Salah satunya yaitu dengan menerapkan strategi pembelajaran writing to learn, sebagaimana telah ada penelitian sebelumnya yang berhasil meningkatkan kemampuan kognitif dan keterampilan berpikir kritis siswa pada pembelajaran fisika dengan menerapkan strategi tersebut, salah satunya yaitu penelitian yang dilakukan oleh Melida (2016) dengan judul "Implementasi strategi writing to learn untuk meningkatkan kemampuan kognitif dan keterampilan berpikir kritis siswa sma pada materi hukum newton."

\section{SIMPULAN}

Hasil penelitian menunjukkan bahwa pada kemampuan kogitif, 62,00\% siswa mampu dalam ranah kognitif $\mathrm{C} 1 ; 31,30 \%$ siswa mampu dalam ranah kognitif $\mathrm{C} 2 ; 21,30 \%$ siswa mampu dalam ranah kognitif $\mathrm{C} 3 ; 25,00 \%$ siswa mampu dalam ranah kognitif $\mathrm{C} 4$; dan pada keterampilan berpikir kritis siswa yaitu, $28 \%$ siswa mampu dalam indikator mengidentifikasi alasan yang dinyatakan; 10,67\% siswa mampu dalam indikator persetujuan di antara sumber; 11,33\% siswa mampu dalam indikator menyimpulkan penjelasan, kesimpulan, dan hipotesis; serta 6,00\% siswa mampu dalam indikator memilih kriteria untuk mempertimbangkan solusi yang mungkin. Implikasinya, kemampuan kognitif dan keterampilan berpikir kritis siswa masih tergolong rendah, sehingga harus ada upaya untuk meningkatkannya melalui inovasi-inovasi pembelajaran.

Saran

Salah satu upaya untuk meningkatkan kemampuan kognitif dan keterampilan berpikir kritis siswa dapat dilakukan melalui inovasi pembelajaran sebagai berikut: (1) Penerapan strategi writing to learn yang dilaksanakan selama proses pembelajaran di dalam kelas; (2) Pemberian tugas menulis yang dikerjakan setelah selesai pembelajaran di dalam kelas setiap pertemuannya pada materi terkait.

\section{UCAPAN TERIMAKASIH}

Penulis mengucapkan banyak terima kasih kepada Kepala sekolah tempat penelitian, guru pengampu mata pelajaran, serta siswa SMA kelas XI yang sangat membantu dan mendukung pelaksanaan penelitian. 


\section{REFERENSI}

Arikunto, S 2012, Dasar-Dasar Evaluasi Pendidikan, Bumi Aksara, Jakarta.

Departemen Pendidikan dan Kebudayaan 2016, Standar Isi Pendidikan Dasar dan Menengah, Depdikbud, Jakarta.

Ennis, R.H 1985, 'A Logical Basis for Measuring Critical Thinking Skills', Association for Supervision and Curriculum Development, pp. 44-48.

Krathwohl, D.R 2002, ‘A Revision of Bloom's Taksonomy: An Overview’ Theory Into Practice, vol. 41, no. 4, pp. 212-218.

Lai, E.R 2011, 'Critical thinking: A literature review', Pearson's Research Reports.

Melida, H. N 2016, 'Implementasi strategi writing to learn untuk meningkatkan kemampuan kognitif dan keterampilan berpikir kritis siswa SMA pada materi hukum newton', Jurnal Penelitian \& Pengembangan Pendidikan Fisika, vol. 2, no. 2, pp. 31-38.

Stiggins, R.J 1994, Student-Centered Classroom Assesment, Macmillan College Publishing Company, New York.

Utari, R 2012, Taksonomi Bloom: Apa dan Bagaimana Menggunakannya?, Pusdiklat KNPK, Widyaiswara Madya.

Yu, KC, Lin, KY \& Fan, SC 2014, ' An exploratory study on application of conceptual knowledge and critical thinking to technological issues', Int J Technol Des Educ. 